\title{
Penggunaan ragi roti (Saccharomyces cereviciae) secara in situ untuk meningkatkan respon kebal non-spesifik ikan nila (Oreochromis niloticus)
}

\section{(The use of Saccharomyces cereviciae in situ to enhance non-specific immune response of nile tilapia, Oreochromis niloticus)}

\author{
Meilina E. Rawung, Henky Manoppo
}

\begin{abstract}
The objetive of research was to examine the effect of yeast cell Saccharomyces cereviciae on non-specific immune response of nile tilapia, Oreochromis niloticus. Juveniles weighing $31.83 \mathrm{~g}$ in average were cultured in five concrete tanks with a density of 30 fish per tank. The fish were fed pellet supplemented with yeast cell at five different doses $(0,10,20$, $30,40 \mathrm{~g} / \mathrm{kg}$ pellet) for three consecutive weeks as much as $4 \% / \mathrm{bb} / \mathrm{day}$, twice daily. At the end of feeding, three fish from each tank were sampled to measure the immune parameters namely total leucocyte count and phagocytosis activity of phagocyte cells. Research results showed that after three weeks of feeding, total leucocyte and phagocytosis activity of fish fed pellet supplemented with yeast cells were significantly different as compared to those of control fish. The highest total leucocyte and phagocytosis activity were achieved in fish fed pellet supplemented with $10 \mathrm{~g}$ of yeast cells $/ \mathrm{kg}$ pellet. It was concluded that the use of yeast cells for three weeks could enhance the nonspecific immune response of nile tilapia.
\end{abstract}

Keywords: Saccharomyces cerreviciae, nonspecific immune response, total leucocyte count, phagocytosis activity, nile tilapia, Oreochromis niloticus

\section{PENDAHULUAN}

Dalam usaha budidaya penyakit merupakan masalah seirus yang sering dihadapi para petani ikan atau pengusaha. Agar peningkatan produksi dalam budidaya ikan dapat berkesinambungan, baik secara ekologi maupun ekonomi, maka kontrol penyakit harus menjadi prioritas utama. Beberapa metode yang telah diterapkan dalam mengontrol penyakit antara lain penggunaan antibiotik atau bahan kimia, vaksin, probiotik, dan imunostimulan. Penggunaan antibiotik dalam kolam telah mengakibatkan munculnya patogen yang tahan terhadap antibiotik (antibiotic-resistant pathogen).
Selain itu, pemberian antibiotik dalam kolam membutuhkan sejumlah besar bahan yang mahal dan dapat terakumulasi dalam tubuh ikan/udang atau lingkungan budidaya dan membahayakan kesehatan konsumen. Vaksin telah digunakan pada beberapa spesies ikan dan memperlihatkan hasil positif.Saat ini beberapa jenis vaksin sudah tersedia dan sudah memperlihatkan hasil yang baik, seperti vaksin Aeromonas hydrophila. Namun demikian, harga vaksin masih mahal dan proteksi yang dihasilkan bersifat spesifik sehingga tidak efektif melawan beberapa patogen secara simultan. 
Salah satu cara yang efektif dalam penanggulangan penyakit adalah dengan menggunakan bahan-bahan alami sebagai imunostimulan. Saat ini, penggunaan imunostimulan semakin mendapat perhatian untuk dikembangkan sebagai metode kontrol penyakit dalam budidaya baik ikan maupun udang. Banyak bukti telah memperlihatkan bahwa imunostimulan yang ditambahkan dalam pakan dapat meningkatkan resistensi ikan dan udang terhadap infeksi penyakit melalui peningkatan respon imun nonspesifik (Pais et al. 2008; Welker et al. 2007).

Imunostimulan merupakan suatu bahan yang dapat meningkatkan atau merangsang sistem imun ikan dengan cara berinteraksi secara langsung dengan sel-sel yang mengaktifkan sistem imun (Gannam and Schrok 2001). Mekanisme kerja imunostimulan dalam merangsang sistem imun adalah dengan cara meningkatkan aktifitas sel-sel fagosit (Yin et al. 2006). Beberapa hasil penelitian sudah memperlihatkan ikan yang diberi makan dengan imunostimulan alami mengalami peningkatan sistem kekebalan tubuh dan nafsu makan ikan meningkat. Salah satu bahan yang berpotensi sebagai imunostimulan adalah ragi roti (Saccharomyces cereviciae) maupun produk samping dari industri ragi roti (yeast-by product) (Olivia-Teles and Goncalves 2001). Penelitian ini menggunakan ragi roti sebagai imunostimulan dengan tujuan untuk mengkaji penggunaan ragi roti secara in situ dalam meningkatkan respon kebal non-spesifik ikan nila.

\section{METODE PENELITIAN}

\section{Hewan Uji}

Hewan uji yang akan digunakan adalah ikan nila dengan ukuran rata-rata 31,83 g/ekor sebanyak 150 ekor. Ikan nila diperoleh dari stok ikan nila yang tersedia di kolam percobaan milik Program Studi Budidaya Perairan Fakultas Perikanan dan Ilmu Kelautan Universitas Sam Ratulangi.

\section{Bahan uji}

Bahan uji adalah ragi roti komersil (Fermipan) yang diperoleh dari toko atausupermarket. Sedangkan pakan pelet yang digunakan adalah pakan tenggelam (merek comfeed $\mathrm{Mg}$ 1) yang memiliki komposisi protein $30 \%$, lemak $6 \%$, serat kasar 5\%, abu $10 \%$ dan kandungan air $12 \%$.

\section{Persiapan pakan}

Dalam persiapan pembuatan pakan, pertama-tama ragi roti ditimbang sesuai dosis yang ditetapkan yakni $0,10,20,30$ dan 40 g. Penimbangan ragi roti menggunakan timbangan digital dengan ketelitian 0,01 g. Setelah ditimbang, ragi roti dimasukkan kedalam wadah erlenmeyer yang sebelumnya telah diisi dengan aquades sebanyak $100 \mathrm{ml}$ untuk 1 kg pakan (10\%). Setelah itu ragi roti diaduk hingga tersuspensi secara merata dalam air, kemudian dicampurkan pada pakan pelet secara merata dengan menggunakan semprotan (sprayer). Campuran pakan dan ragi roti tersebut selanjutnya dikering-anginkan dalam temperatur ruang.Kemudian pelet selanjutnya dimasukan dalam kantong plastik dan disimpan dalam lemari pendingin sampai saat digunakan. 


\section{Prosedur Percobaan dan Pengambilan Data}

Ikan untuk keperluan penelitian ditangkap dari kolam percobaan kemudian dipindahkan ke dalam lima buah bak beton masing-masing berukuran 2x1x $\mathrm{m}^{3}$ dengan padat tebar 30 ekor/bak. Setiap bak diisi dengan air setinggi $50 \mathrm{~cm}$ dan dilengkapi dengan sebuah pompa air kecil untuk resirkulasi. Sebelum pakan perlakuan diberikan ikan diadaptasikan terlebih dahulu di dalam bak selama satu minggu. Selama proses tersebut ikan diberi pakan pelet yang belum ditambahkan ragi roti dengan dosis 4\% / BB / hari dengan frekuensi pemberian 2 kali sehari yaitu jam 08.00 pagi dan 17.00 sore. Setelah proses adaptasi selesai, ikan diberi pakan perlakuan dengan dosis dan waktu yang sama yang diberikan saat adaptasi yaitu 4\% / BB / hari dan diberikan 2 kali sehari. Perlakuan yang dicobakan adalah $\mathrm{A}=0 \mathrm{~g} / \mathrm{kg}$ pakan, $\mathrm{B}=10 \mathrm{~g} / \mathrm{kg}$ pakan, $\mathrm{C}=20 \mathrm{~g} / \mathrm{kg}$ pakan, $\mathrm{D}=30 \mathrm{~g} / \mathrm{kg}$ pakan, $\mathrm{E}=40 \mathrm{~g} / \mathrm{kg}$ pakan. Data yang dikumpulkan yaitu data parameter imun yang terdiri dari TLC (Total Leukosit Count) dan aktifitas fagositosis.

\section{a.Total Leukosit}

Untuk mengukur parameter imun maka pertama-tama dilakukan pengambilan sampel darah ikan yang dikerjakan menurut prosedur yang dikemukakan oleh Stolen et al.(1990). Sampel darah ikan diambil dari 3 ekor ikan dari setiap bak dengan menggunakan spuit yang sebelumnya sudah dibilas terlebih dahulu dengan menggunakan EDTA sebagai anti koagulan. Sampel darah ikan diambil dari vena caudalis.

Untuk menghitung jumlah leukosit, darah diambil sebanyak $0,5 \mathrm{ml}$ dengan menggunakan mikro pipet dan dimasukkan ke dalam tabung eppendorf yang sudah dibilas dengan heparin anti koagulan sebelumnya. Kemudian larutan Turk's diambil sebanyak $500 \mu$ l dan dimasukkan ke dalam eppendorf yang telah berisi darah sebelumnya dengan perbandingan darah dan larutann Turk's yaitu 1:10. Fungsi larutan Turk's adalah untuk menghancurkan sel darah merah.Campuran darah dan larutan Turk's dihomogenkan dengan mengayun-ayunkan secara perlahan-lahan dan diinkubasi dalam suhu ruang selama 5 menit, salanjutnya sel darah dihitung dengan menggunakan hemasitometer dengan bantuan mikroskop cahaya pada pembesaran 100x.

\section{b. Aktifitas Fagositosis}

Untuk mengukur aktifitas fagositosis, pertama-tama sampel darah sebanyak $50 \mu \mathrm{l}$ dimasukan ke dalam tabung eppendorf steril dan ditambahkan $50 \mu \mathrm{l}$ suspensi sel ragi roti. Larutan campuran darah dan ragi roti ini selanjutnya dihomogenkan dengan cara diayunkan perlahan-lahan dan diinkubasi dalam suhu ruang selama 20 menit. Selanjutnya $5 \mu \mathrm{l}$ sampel campuran darah dan ragi roti dibuat sediaan ulas menggunakan kaca preparat dan sedian ulas dikering-anginkan dalam suhu ruang. Proses selanjutnya adalah melakukan pewarnaan Giemsa. Proses pewarnaan sediaan ulas dengan Giemsa dikerjakan sesuai dengan prosedur Pritchard and Kruse (1988). Sel yang menunjukan proses fagositosis ditandai dengan adanya sel-sel ragi roti yang menempel pada permukaan sel fagosit atau terdapat di dalam sitoplasma sel. Aktifitas fagositosis diamati dari 50 sampai 100 sel yang 
teramati. Aktifitas fagositosis dihitung dengan rumus:

Aktifitas Fagositosis (\%) = (Jumlah sel fagosit yang melakukan pemangsaan/ Jumlah sel fagosit teramati) x100

\section{Analisis Data}

Pengaruh perlakuan ragi roti terhadap peningkatan respon kebal nonspesifik ikan nila dianalisis dengan menggunakan analisis ragam (Anova). Apabila perlakuan memberikan pengaruh nyata maka dilanjutkan dengan uji lanjut Duncan guna mengkaji pengaruh perbedaan antar perlakuan terhadap kedua parameter yang diamati. Analisis data menggunakan program SPSS untuk windows.

\section{HASIL DAN PEMBAHASAN}

\section{a. Total Leukosit}

Hasil penelitian memperlihatkan bahwa penambahan ragi roti dalam pakan memberi pengaruh yang nyata $(p=0,04)$ terhadap total leukosit setelah diberikan selama 3 minggu (tabel 1).

Tabel 1. Total Leukosit (x $10^{7} \mathrm{sel} / \mathrm{ml}$ ) ikan nila setelah diberi perlakuan ragi roti selama 3 minggu

\begin{tabular}{|l|l|}
\hline Perlakuan (Ragi roti) & Total Leukosit \\
\hline $\mathrm{A}=0 \mathrm{~g} / \mathrm{kg}$ pakan & $4.05^{\mathrm{a}}$ \\
\hline $\mathrm{B}=10 \mathrm{~g} / \mathrm{kg}$ pakan & $6.04^{\mathrm{b}}$ \\
\hline $\mathrm{C}=20 \mathrm{~g} / \mathrm{kg}$ pakan & $4.74^{\mathrm{ab}}$ \\
\hline $\mathrm{D}=30 \mathrm{~g} / \mathrm{kg}$ pakan & $4.28^{\mathrm{a}}$ \\
\hline $\mathrm{E}=40 \mathrm{~g} / \mathrm{kg}$ pakan & $4.37^{\mathrm{a}}$ \\
\hline
\end{tabular}

Hasil uji lanjut menunjukkan bahwa total leukosit ikan yang diberi perlakuan B (10 g/kg pakan) dan C (20 $\mathrm{g} / \mathrm{kg}$ pakan) berbanding nyata dibandingkan dengan perlakuan C (20 g/kg pakan), E (40 g/kg pakan), D (30 g/kg pakan) dan A (0 g/kg pakan). Antar perlakuan $\mathrm{B}$ dan $\mathrm{C}$ tidak teramati adanya perbedaan nyata sedangkan perlakuan C,D,E dan A tidak berbeda nyata antar satu dengan yang lainnya.

\section{Dari data hasil pengukuran} memperlihatkan total leukosit tertinggi tercapai pada ikan yang diberi pakan dengan penambahan ragi roti $10 \mathrm{~g} / \mathrm{kg}$ pakan dan diikuti oleh perlakuan C. Hasil yang sama dilaporkan oleh Manurung $d k k$ (2013) dimana ikan nila berukuran ratarata 10,57 g dan diberi pakan perlakuan dengan penambahan ragi roti $10 \mathrm{~g} / \mathrm{kg}$ pakan selama 4 minggu memiliki total leukosit yang tertinggi dibandingkan dengan perlakuan lainnya. Tewary and Patra (2011) juga melaporkan bahwa penambahan ragi roti $5 \%$ pada ikan Rohu (Labeho rohita) berukuran rata-rata $12 \mathrm{~g}$ menghasilkan peningkatan total leukosit yang lebih tinggi dibandingkan dengan total leukosit ikan yang diberi pakan tanpa penambahan ragi roti. Perlakuan E memiliki jumlah total leukosit yang sedikit lebih besar dari perlakuan $\mathrm{D}$ dan tidak berbeda nyata dibandingkan dengan perlakuan A. Hal ini menunjukkan bahawa pada dosis yang tinggi ( $\mathrm{E}=40 \mathrm{~g} / \mathrm{kg}$ pakan dan $\mathrm{D}=30 \mathrm{~g} / \mathrm{kg}$ pakan) ragi roti sebagai imunostimulan tidak dapat memacu peningkatan total leukosit tetapi mungkin sebaliknya akan menekan sistim imun. Nampak pada data yang diperoleh, nilai total leukosit ikan yang diberi kedua perlakuan ini adalah kecil dan mendekati jumlah total leukosit ikan yang tidak diberi perlakuan ragi roti (tabel 1). Menurut Sakai (1999), dosis dan lama waktu pemberian merupakan faktor penting yang harus dipertimbangkan dalam pemberian 
suatu imunostimulan. Apabila imunostimulan diberikan dalam dosis yang tinggi atau berlebihan maka respon yang ditimbulkan akan dapat teramati dalam waktu yang singkat namun apabila diberikan dalam waktu yang berkepanjangan, dosis yang tinggi mungkin tidak akan meningkatkan tetapi sebaliknya mungkin menekan respon imun ikan karna bahan tersebut tidak lagi bekerja sebagai imunostimulator tetapi justru akan bekerja sebagai immunosuppresor.

Li and Galtin (2003) menyatakan bahwa ragi roti mengandung bahan-bahan yang berfungsi sebagai immunomodulator seperti nukleotida. Nukleotida adalah nutrient semi esensial dan bahan ini dibutuhkan untuk pertumbuhan dan perbanyakan sel organisme hidup serta mengoptimalkan fungsi-fungsi pembelahan sel termasuk sel-sel imun (Barnes, 2006; Sajeevan et al., 2006). Nukeotida akan diurai oleh enzim nukleotridase untuk melepas molekul fosfat dan menghasilkan nukleosida. Nukleosida kemudian diurai oleh enzim nukleosidase untuk melepas molekul gula dan menghasilkan basa purin dan pirimidin. Purin dan pirimidin akan digunakan untuk membentuk nukleotida yang dibutuhkan untuk pembentukan DNA dan perbanyakan atau pembentukan sel baru.

Menurut Raa (2000), ragi roti banyak mengandung $\beta$-glucan. $\beta$-gucan juga berfungsi sebagai imunostimulan yang dapat meningkatkan respon imun ikan. Bahan ini bekerja sebagai berikatan terlebih dahulu dengan sel-sel fagosit dan setelah berikatan sel akan mengeluarkan sitokin yang merangsang pembentukan sel fagosit yang baru. Dalam penelitian yang dilakukan oleh Misra et al., (2006), ikan rohu (Labeo rohita) dengan berat rata-rata ikan $35 \pm 5$ g yang diberi $\beta$-glucan selama 28 hari memiliki total leukosit yang lebih banyak dibandingkan dengan ikan kontrol. Sahan dan Duman (2010) juga melaporkan bahwa ikan nila yang diberi $\beta$-glucan $0,1 \%$ memiliki total leukosit yang lebih banyak dibandingkan dengan kontrol.

\section{b. Aktifitas Fagositosis}

Aktifitas fagositosis ikan setelah diberi perlakuan ragi roti memperlihatkan perbedaan yang sangat nyata dibandingkan dengan aktifitas fagositosis ikan yang tidak diberi perlakuan ragi roti $(p=0,00)$. Hasil pengukuran aktifitas fagositosis ditunjukkan pada tabel berikut

Tabel 2. Aktifitas Fagositosis (\%) ikan nila setelah diberi perlakuan ragi roti selama 3 minggu

\begin{tabular}{|l|l|}
\hline Perlakuan & $\begin{array}{l}\text { Aktifitas } \\
\text { Fagositosis }^{\text {a }}\end{array}$ \\
\hline $\mathrm{A}=0 \mathrm{~g} / \mathrm{kg}$ pakan & $35.56^{\mathrm{a}}$ \\
\hline $\mathrm{B}=10 \mathrm{~g} / \mathrm{kg}$ pakan & $66.31^{\mathrm{C}}$ \\
\hline $\mathrm{C}=20 \mathrm{~g} / \mathrm{kg}$ pakan & $61.14^{\mathrm{C}}$ \\
\hline $\mathrm{D}=30 \mathrm{~g} / \mathrm{kg}$ pakan & $48.14^{\mathrm{b}}$ \\
\hline $\mathrm{E}=40 \mathrm{~g} / \mathrm{kg}$ pakan & $51.00^{\mathrm{b}}$ \\
\hline
\end{tabular}

Hasil penelitian memperlihatkan bahwa nilai aktifitas fagositosis tertinggi dicapai pada ikan yang diberi pakan dengan penambahan ragi roti sebesar 10 $\mathrm{g} / \mathrm{kg}$ pakan diikuti perlakuan $20 \mathrm{~g} / \mathrm{kg}$ pakan. Nilai tertinggi yang dicapai pada kedua perlakuan ini mungkin berhubungan dengan jumlah total leukosit. Pada tabel 1 terlihat bahwa jumlah leukosit tertinggi dicapai pada perlakuan $10 \mathrm{~g} / \mathrm{kg}$ pakan. Dalam keadaan normal, ikan yang memiliki total leukosit yang tinggi akan 
memperlihatkan aktifitas fagositosis yang tinggi pula. Aktifitas fagositosis ikan pada dosis yang tinggi (40 g/kg pakan dan 30 $\mathrm{g} / \mathrm{kg}$ pakan) memiliki nilai yang hampir sama dan lebih rendah dibandingkan dengan aktifitas fagositosis pada dosis yang lebih kecil (10 g/kg pakan dan 20 g/kg pakan). Hal ini terjadi karena dosis yang diberikan sudah berlebihan (over dosis) sehingga apabila diberikan dalam waktu yang cukup lama, bahan imunostimulan yang ada akan menjadi immunosuppresor.

Hasil uji lanjut Duncan menunjukkan aktifitas fagositosis ikan yang diberi pakan dengan penambahan ragi roti $10 \mathrm{~g} / \mathrm{kg}$ pakan dan $20 \mathrm{~g} / \mathrm{kg}$ pakan berbeda sangat nyata dibandingkan dengan aktifitas fagositosis ikan pada perlakuan kontrol (0 $\mathrm{g} / \mathrm{kg}$ pakan) maupun dibandingkan dengan aktifitas fagositosis ikan pada perlakuan $40 \mathrm{~g} / \mathrm{kg}$ pakan dan 30 $\mathrm{g} / \mathrm{kg}$ pakan. Sekalipun demikian antar perlakuan 10 g/kg pakan dan 20 g/kg pakan tidak terdapat perbedaan nyata. Aktifitas fagositosis ikan pada perlakuan $40 \mathrm{~g} / \mathrm{kg}$ pakan dan $30 \mathrm{~g} / \mathrm{kg}$ pakan juga berbeda sangat nyata dibandingkan dengan aktifitas fagositosis pada ikan kontrol namun tidak antar kedua perlakuan tersebut tidak berbeda nyata (tabel 2).

Ragi roti dapat meningkatkan aktifitas fagositosis karena bahan ini selain mengandung asam nulkleat, mannan, dan nukleotida, juga mengandung $\beta$-glucan maupun (Li and Galtin, 2003 ; 2006). Menurut Raa (2000), $\beta$-glucan meningkatkan aktifitas fagositosis dengan cara berikatan terlebih dahulu dengan molekul reseptor yang terdapat pada permukaan sel-sel fagosit. Setelah berikatan maka sel fagosit akan diaktifkan untuk melakukan proses fagositosis terhadap partikel asing atau bakteri yang masuk kedalam tubuh. Dalam penelitian ini didapatkan bahwa pemberian ragi roti selama 3 minggu mampu meningkatkan aktifitas fagositosis dimana pemberian 10 g/kg pakan memiliki nilai terbaik. Sakai et al., (2001) juga mendapatkan pemberian ekstrak ragi roti $15 \mathrm{mg} /$ ikan memperlihatkan peningkatan aktifitas fagositosis. Dalam penelitian yang dilakukan oleh Misra et al., (2006), pemberian $\beta$-glucan secara nyata meningkatkan aktifitas fagositosis pada ikan rohu (L.rohita). Manurung (2013) mendapatkan hasil yang sama dimana ikan nila yang dibepelihara di akuarium dan diberi ragi roti $10-20 \mathrm{~g} / \mathrm{kg}$ pakan memiliki aktifitas fagositosis yang lebih tinggi dibandingkan dengan ikan kontrol.

Nukleotida yang terkandung dalam ragi roti juga dapat meningkatkan aktifitas fagositosis ikan. Hasil penelitian Labora (2012), memperlihatkan pemberian nukleotida 300 mg pada ikan nila selama 3-4 minggu meningkatkan aktifitas fagositosis dan berbeda nyata dibandingkan dengan kontrol.

\section{KESIMPULAN}

Pemeberian ragi roti secara oral dengan dosis $10 \mathrm{~g} / \mathrm{kg}$ pakan mampu meningkatkan respon imun non-spesifik setelah diberikan selama tiga minggu berturut-turut.

\section{DAFTAR PUSTAKA}

Barnes A. 2006. Dietary nucleotides:

Essential nutrients for shrimp growth and immunity. Centre for Marine Studies, University of Queensland. 
Gannam AL, and Schrock RM. 2001. Imunostimulant in fish diet diacu dalam Nutrion and Fish Health. Food Products Press, New York. P: 235-260

Li P, Galtin III DM. 2003. Evaluation of brewers' yeast (Saccharomyces cerevisiae) as a feed supplement for hybrid striped bass (Marone chrysops $x$ M. saxatillis). Aquac 219: 681-692

Li P, Gatlin III DM. 2006. Nucleotide nutrition in fish: Current knowledge and fiture application. Aquac $251: 141-152$.

Manurung US. 2013. Evaluasi Ragi Roti (Saccharomyces cereviciae) sebagai imunostimulan dalam meningkatkan respon imun nonspesifik dan pertumbuhan ikan nila (Oreochromis niloticus). Fakultas Perikanan Dan Ilmu Kelautan UNSRAT (Skripsi). Manado.

Manurung US, Manoppo H, Tumbol RA. 2013. Evaluation of Baker's Yeast (Saccharomyces cereviciae) In Enhancing Non Specific Immune Response and Growth of Nile Tilapia (Oreochromis niloticus). ejournal Budidaya Perairan Vol.1 No. 1: 8-14

Misra CK, Das BK, Mukherjee SC, Pattnaik P. 2006. Effect of longterm administration of dietary $\beta$ glucan on immunity, growth and resistance of Labeo rohita fingerlings. Aquac 255: 82-92

Olivia-Teles A, Goncalves P. 2001.

Partisial replacement of fishmeal by brewers yeast Saccaromyces cerevisiae, in diets for sea bass Dicentrachus labrax juveniles. Aquaculture 202: 269'278.

Pais R, Khushiramani R, Karunasagar I,
Karunasagar I. 2008. Effect of immunostimulants on hemolymph haemagglutinins of tiger shrimp Penaeus monodon. Aquac Res 38: 1339-1345

Pritchard MH, Kruse GOW. 1982. The Collection and Preservation of Animal Parasites. University of Nebraska Press, London.

Raa J. 2000. The use of immunestimulants in fish and shellfish feeds. University of Tromso Norway

Sahan A, Duman S. 2010. Effect of $\beta$ glucan on Haematology of Common Carp (Cyprinus carpio) Infected by Ectoparasites. Journal Mediterranean Aquaculture. 1 (1); 1-7

Sajeevan TP, Philip R, Singh ISB. 2006. Immunostimulatory effect of a marine yeast Candida sake S156 Fenneropenaeus indicus. Aquac 257: 150-155.

Sakai M. 1999. Current Research Status of Fish Imunostimulants. Aquaculture 172 : 63-92.

Sakai M, Taniguchi K, Mamoto K, Ogawa H, Tabata M. 2001. Immunostimulant effects of nucleotide isolated from yeast RNA on crap, Cyprinus carpio L. J Fish Dis 24: 433-438.

Stolen SJ. 1990. Techniques in immunologi. 1 st edition. SOS Publication 43 de Normandie A Venue Fair Haven, NJ 07703-3303.

Tewary P, Patra BC. 2011. Oral administration of baker's yeast (Saccharomyces cerevisiae) acts as a growth promoter and immunomodulator in Labeo rohita (Ham.) 
Welker TL, Lim C, Aksoy MY, Shelby R, Klesius PH. 2007. Immune response and resistance to stress and Edwarsiella ictaluri challenge in channel catfish, Ictalurus punctatus, fed diet containing commercial whole-cell yeast or yeast subcomponents. J World Aquac Soc Vol. 38 No. 1:24-31
Yin G, Jeney G, Racz Y, Pao X, Jeney Z. 2006. Effect of two Chinese herbs (Astragalus radix and Scutellaria radix) on non-spesifik immune response of tilapia, Oreochromis niloticus. Aquaculture 235 : 39-47. 